\title{
Burned Area Mapping over the Southern Cape Forestry Region, South Africa Using Sentinel Data within GEE Cloud Platform
}

\author{
Sifiso Xulu ${ }^{1, *(1)}$, Nkanyiso Mbatha ${ }^{2}\left(\mathbb{D}\right.$ and Kabir Peerbhay ${ }^{3}$ \\ 1 Department of Geography, University of the Free State, Phuthaditjhaba 9869, South Africa \\ 2 Department of Geography and Environmental Studies, University of Zululand, \\ KwaDlangezwa 3886, South Africa; MbathaNB@unizulu.ac.za \\ 3 School of Agricultural, Earth and Environmental Sciences, University of KwaZulu-Natal, Westville Campus, \\ Durban 4000, South Africa; Kabir.Peerbhay@sappi.com \\ * Correspondence: xulus@ufs.ac.za; Tel.: +27-058-718-5279
}

check for

updates

Citation: Xulu, S.; Mbatha, N.; Peerbhay, K. Burned Area Mapping over the Southern Cape Forestry Region, South Africa Using Sentinel Data within GEE Cloud Platform. ISPRS Int. J. Geo-Inf. 2021, 10, 511. https://doi.org/10.3390/ijgi10080511

Academic Editors: Wolfgang Kainz,

Palaiologos Palaiologou and Kostas Kalabokidis

Received: 10 May 2021

Accepted: 21 July 2021

Published: 28 July 2021

Publisher's Note: MDPI stays neutral with regard to jurisdictional claims in published maps and institutional affiliations.

Copyright: (c) 2021 by the authors. Licensee MDPI, Basel, Switzerland. This article is an open access article distributed under the terms and conditions of the Creative Commons Attribution (CC BY) license (https:// creativecommons.org/licenses/by/ $4.0 /)$.

\begin{abstract}
Planted forests in South Africa have been affected by an increasing number of economically damaging fires over the past four decades. They constitute a major threat to the forestry industry and account for over $80 \%$ of the country's commercial timber losses. Forest fires are more frequent and severe during the drier drought conditions that are typical in South Africa. For proper forest management, accurate detection and mapping of burned areas are required, yet the exercise is difficult to perform in the field because of time and expense. Now that ready-to-use satellite data are freely accessible in the cloud-based Google Earth Engine (GEE), in this study, we exploit the Sentinel-2-derived differenced normalized burned ratio (dNBR) to characterize burn severity areas, and also track carbon monoxide (CO) plumes using Sentinel-5 following a wildfire that broke over the southeastern coast of the Western Cape province in late October 2018. The results showed that $37.4 \%$ of the area was severely burned, and much of it occurred in forested land in the studied area. This was followed by $24.7 \%$ of the area that was burned at a moderate-high level. About $15.9 \%$ had moderate-low burned severity, whereas $21.9 \%$ was slightly burned. Random forests classifier was adopted to separate burned class from unburned and achieved an overall accuracy of over $97 \%$. The most important variables in the classification included texture, NBR, and the NIR bands. The CO signal sharply increased during fire outbreaks and marked the intensity of black carbon over the affected area. Our study contributes to the understanding of forest fire in the dynamics over the Southern Cape forestry landscape. Furthermore, it also demonstrates the usefulness of Sentinel-5 for monitoring CO. Taken together, the Sentinel satellites and GEE offer an effective tool for mapping fires, even in data-poor countries.
\end{abstract}

Keywords: forest fire; burned area; NBR; Sentinel-2; Sentinel-5; GEE; time series analysis

\section{Introduction}

Commercial plantation forests in South Africa are repeatedly exposed to various disturbances such as insect pests [1], and disease [2], invasive alien species [3], drought stress [4], and fire [5]. Of these, fire constitutes the greatest threat to the sustainability of the country's forestry industry as it accounts for nearly $87 \%$ of the losses suffered by commercial plantations [5]. This warrants concern because nearly 600,000 ha of damaged plantations has been attributed to forest fires since 1980 [5], and this problem is expected to increase with climate warming. The impact of forest fires has a large bearing on the country's economy; for example, the 2017 fires in the Southern Cape Forestry region cost R2 billion (USD 134,998,460) to the South African insurance industry [6]. Additional costs are incurred when trees younger than harvesting age are accidentally burned, which then require felling, clearing, and replanting [5]. Moreover, forest fires are known to influence atmospheric processes by freeing large quantities of carbon [7], provoke plants with in- 
vasive characteristics [8], alter forest structure [9], and threaten the lives of communities living on the periphery of forested areas [10].

The formulation of suppression and monitoring strategies against forest fires necessitates reliable information on fire behavior, particularly with regard to those factors that create favorable conditions for fire outbreaks [11,12]. Several studies have associated forest fires with a variety of factors such as forest canopy fuels [13], amplified sources of ignition linked to the human population [14], the proliferation of flammable plants [15] and drought $[16,17]$. Hitherto, a growing number of studies report the increase in forest fires in the tropics and subtropics during extended drought conditions [18-21]. These conditions are typical of the forestry region of South Africa in the Western Cape province [22], where this study is conducted. The vulnerability of this region to destructive forests fires is attributed to the synergistic effects of drought and flammable fynbos vegetation, which simultaneously are conducive to fires [23]. This is a great concern to the stability of the forestry industry [24] since the probability of similar fires in the future is growing [25].

During late October and early November 2018, relatively dry weather conditions prevailed over the southern Cape forestry region and created favorable conditions for forest fires that destroyed extensive areas of plantation forests [26]. Two wildfires occurred in succession, the first broke from human-induced point ignition on the 24th October and the second incident was ignited by lightning on the 29th October [26]. This was by far the most intense and widespread fire incident, surpassing all wildfires in this region in the previous century [27]. What may exacerbate matters further is that trees damaged by fires are prone to diseases, and may add additional management costs to the forestry industry [28]. As such, forest fires have become a common feature of the Southern Cape forestry region and an inevitable consequence of the country's fire-prone vegetation and warm, dry climate [28]. Hitherto, information on burned land use/cover classes in this area remains inconclusive, and this provides a partial explanation of why this study was purposefully devised.

The assessment of forest fire generally involves field surveys, which are efficiently conducted for small areas [29]. However, the assessment of forest damage in larger areas is difficult and expensive [30]. Given the expected rise in forest fires globally [31], innovative computing approaches using remote sensing are required to deliver quicker and affordable evaluations of larger affected areas [32] and have been successfully adopted to evaluate burn severity worldwide [33-35]. Remote sensing enables the systematic and flexible recording of burned areas and also provides insights into the agents responsible for these outcomes [36]. Besides burnt area mapping, remote sensing is used successfully to detect active fires [37].

The manifestation of forest fires was detected by means of near-daily satellite platforms such as the Advanced Very High Resolution Radiometer (AVHRR), Moderate Resolution Imaging Spectrometer (MODIS), and Medium Resolution Imaging Spectrometer (MERIS) with coarse $(>250 \mathrm{~m})$ spatial resolution $[38,39]$. Their near-daily revisit cycle is valuable and practical to record fire signatures, but they are unavailable to detect small burned areas, particularly in regions with limited and highly fragmented fires [40,41]. In such areas, these satellite products also suffer methodological limitations in respect of assigning specific vegetation types to the burned area [42], which are crucial for understanding the ecological effects of fire [43]. Because accurate information on burned areas is a prerequisite for effective fire management [44], fine-scale satellite imagery is required to provide a reliable depiction of burned areas [45]. The Sentinel satellite constellations are uniquely suited to monitor forest fires as they provide unrestricted high-resolution images with near-daily acquisitions [46,47], the only one of its kind to deliver rich and affordable global observations so far. This facility also includes the monitoring of fire-emitted gases such as carbon monoxide (CO) with the latest Sentinel-5 sensor [48]. However, the lack of processing tools for these datasets is a major constraint on their utilization, particularly in countries with limited resources. 
The emergence of unrestricted cloud-based computing resources such as Google Earth Engine (GEE) has enabled unprecedented access to petabytes of geospatial data (i.e., complete Sentinels archive) with diverse processing functions, and this has leveled the ground for users in data-poor countries and their counterparts [49]. The GEE's powerful parallel computing infrastructure facilitates on-demand and on-the-fly production of complex geospatial products at varying geographic and time scales without the necessity of supercomputers [50,51]. Its capabilities were demonstrated in various applications [52], however, few studies have exploited GEE for burned area monitoring over forested landscapes so far [53]. For example, Bar et al. [54] compared the performance of three machine learning approaches for forest fire burned area detection based on Sentinel-2 and Landsat-8 data within the GEE framework. Their results showed superior classification accuracies of 97-100\% for classification regression tree (CART) and RF algorithms, while the support vector machine (SVM) achieved slightly lower accuracy. Similarly, Seydi et al. [55], used Sentinel-2 and machine learning algorithms within the GEE platform to detect wildfire damage in Australia, and they detected burned areas with accuracies from $82 \%$ to $92 \%$. Konkathi and Shetty [53] also compared post-fire burn severity indices from Sentinel-2 and Landsat-8 and achieved comparable results in mapping burn severity for both sensors; the relativized NBR showed high accuracy over heterogeneous landscapes followed by dNBR and the relativized burn ratio performed relatively weaker. Castillo et al. [56] successfully mapped Amazon Forests with accuracies from $82 \%$ to $98 \%$ using Sentinel-2 and Landsat- 8 images within the GEE environment. In addition, studies such as Praticò et al. [57] exploited machine learning algorithms within GEE to classify Mediterranean forest landscape, and their results successfully achieved accuracies from $80 \%$ to $83 \%$ based on Sentinel-2 with RF and SVM. These studies have demonstrated high potential for GEE to monitor fire-induced forest damage, and as such, burned area mapping is expected to increase because users have access to these facilities wherever they are located.

Sentinel-2 has become an attractive source for burned area monitoring because of its superior spectral properties, including the red-edge bands suited for chlorophyll content characterization [58], which provides the means to create novel indices for burn severity mapping [59]. Several previous studies have evaluated forest fires using the normalized burn ratio (NBR) with a high degree of success $[47,60]$. The NBR exploits the near-infrared (NIR) and short-wave infrared (SWIR) regions of the electromagnetic spectrum [61]. This index is well-suited to detect fires in vegetation because the variations in the NIR usually represent the changes in the photosynthetically active vegetation, which is reduced by fire, whereas the modifications in the SWIR reflect moisture content [62,63]. Indeed, fire results in a sharp contrast between the NIR and SWIR records [64]. Additionally, previous studies have used the NBR variants, of which the differenced normalized burn ratio (dNBR) is commonly applied [65]. The dNBR is a bi-temporal image differencing performed on preand post-fire NBR images [64,66], to distinguish burn severity levels [65]. The fire categorybased dNBR has become a practical reference to obtain burn severity information $[67,68]$.

In this study, we present a quick and affordable method for monitoring burned forest areas using Sentinel-2-derived NBR and dNBR indices within the GEE framework. Furthermore, we demonstrate the capacity of data from the recently launched Sentinel-5 satellite to track $\mathrm{CO}$ as one of the trace gases emitted during the burning of vegetation.

\section{Materials and Methods}

\subsection{Study Area}

This study was conducted in the southern Cape forestry region of South Africa, between the towns of George $\left(33.97^{\circ} \mathrm{S}, 22.75^{\circ} \mathrm{E}\right)$ and Knysna $\left(34.22^{\circ} \mathrm{S}, 23.28^{\circ} \mathrm{E}\right)$, extending towards the foothills of the Outeniqua Mountains in the Eden District Municipality of the Western Cape province (Figure 1). Elevation ranges from 150 to $1400 \mathrm{~m}$ above sea level. Ecologically, this area falls in the eastern coastal fynbos shrublands, which are in a poorly studied part of the Cape Floral Kingdom (CFK) [69]. 


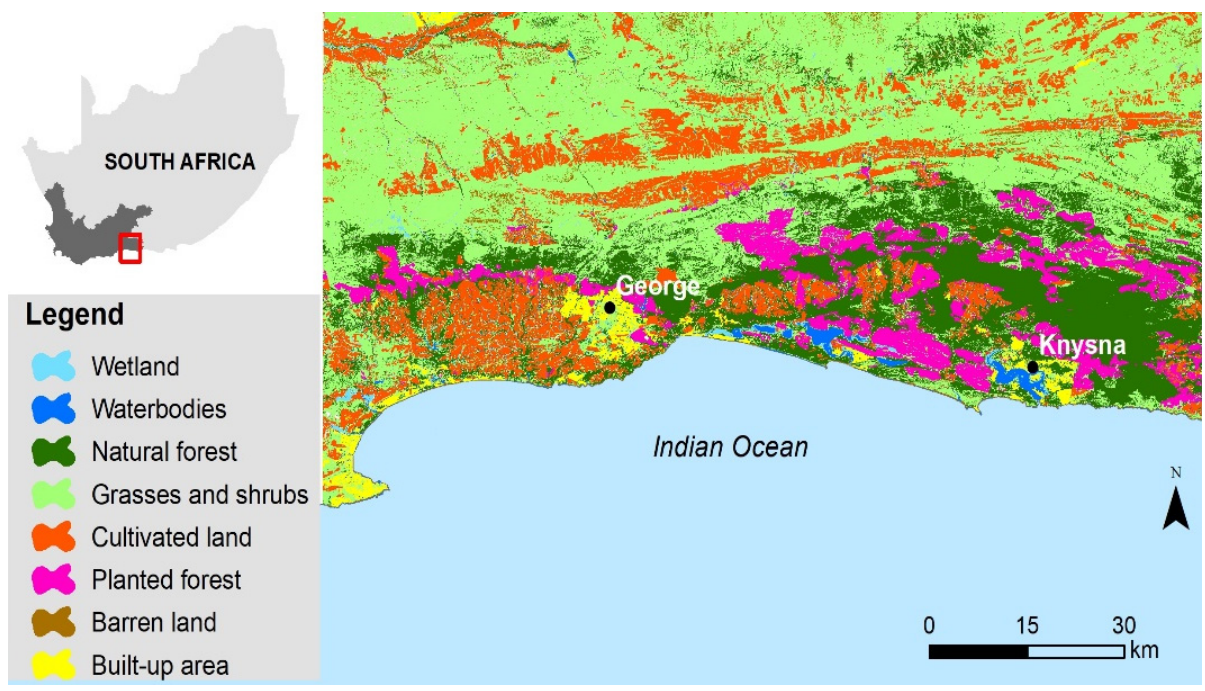

Figure 1. Location of the study area in the Western Cape province, South Africa.

The main vegetation type across the area studied, as shown in Figure 1, includes commercial plantation and natural forests as well as the fire-prone fynbos vegetation, comprising fine-leaved, medium-sized sclerophyllous shrubs, which are highly flammable [70]. Plantation forests have become fragmented and dispersed and replaced large areas of fynbos [71]. The area has a temperate climate with average rainfall ranging from 800 to $1078 \mathrm{~mm}$ throughout the year (peaking in April and October); the daily average temperatures are $20^{\circ} \mathrm{C}$ in summer and $12{ }^{\circ} \mathrm{C}$ in winter [72]. Hot and dry katabatic winds prevail in autumn and winter and are associated with highly threatening fire conditions [69]. Despite this pattern, fires occur throughout the year in this region as overall weather conditions suitable for fire are progressively less seasonal towards the studied area [69].

\subsection{Burned Severity and Quantification of Burn Area for Each Land Use/Cover Class}

The 10-m Sentinel-2 constellation with its combined potential 5-day revisiting period has become attractive for time-sensitive events such as burned-area mapping. The Sentinel-2 datasets usable for vegetation mapping were extracted and processed through the JavaScript code editor in the Google Earth Engine platform. All the images we used were near cloud-free. We filtered imagery dates predating (16 October) and postdating (12 November) the fire event to enable the computation of normalized burned ratio (NBR; Key and Benson [61]) — the most widely used index for the mapping of burned areas. NBR is calculated as the difference between the near-infrared (NIR) and shortwave near-infrared (SWIR) bands over their sum (Equation (1)). The basis of the NBR is that fire alters vegetation so that its removal and replacement by charcoal spectrally reduces the NIR and increases the SWIR signals [64].

$$
\mathrm{NBR}=\frac{\mathrm{NIR}-\mathrm{SWIR}}{\mathrm{NIR}+\mathrm{SWIR}}
$$

Using NBR as defined in Equation (1), we calculated the dNBR as illustrated in Equation (2). The dNBR has become a standard fire severity measurement [60] as it is a criterion to understand burned severity levels [66]. The dNBR ranges from -2 to +2 with high positive values representing severely burned areas. The severity levels proposed by Key and Benson [64] are listed in Table 1.

$$
\mathrm{dNBR}=\mathrm{NBR}_{\text {prefire }}-\mathrm{NBR}_{\text {postfire }}
$$


Table 1. Severity levels and the differenced normalized burn ratio (dNBR) range.

\begin{tabular}{lcc}
\hline Severity Level & Color Code & dNBR Values \\
\hline Unburned & & $<-0.1$ \\
Low severity & & $0.1-0.26$ \\
Moderate-low & $0.27-0.43$ \\
Moderate-high & $0.44-0.65$ \\
High severity & $>0.66$ \\
\hline
\end{tabular}

We also adjusted the dates corresponding to the fire record and used the SWIR (B12, $1290 \mathrm{~nm}), \operatorname{NIR}(B 08,842 \mathrm{~nm})$ and red (B04, $665 \mathrm{~nm})$ bands to display active fire and smoke. Here, we highlight the prominence of Sentinel-2 data for active fire detection as a verification tool, particularly fire incidents that span five days or more.

The South African Land Cover Classification for 2018 was used to extract polygons for each class within the study area in Environmental Systems Research Institute (ESRI)'s ArcMap environment. The polygon for each class was ingested into the GEE, after which burned severity was calculated. Polygons with large geometry were split to enable the computation of burned areas.

\subsection{Carbon Monoxide and Black Carbon Data}

The Sentinel-5 Precursor satellite launched on 13 October 2017, carrying the Tropospheric Monitoring Instrument (TROPOMI), provides daily global information on the concentrations of key atmospheric constituents, including carbon monoxide (CO) [73]. TROPOMI observes the global atmosphere daily with a fine resolution of $7 \mathrm{~km} \times 3.5 \mathrm{~km} \mathrm{[74]}$ and enables the detection of even smaller CO plumes. In this study, we used TROPOMI Offline stream through the GEE code editor to assess the CO column density over the southern Cape forestry region where forest fires between late October and early November 2018 destroyed plantations near the town of George.

Black carbon surface mass concentration data obtained from the Modern Retrospective Analysis for the Research Application (MERRA-2) model were used in this study. Additionally, this is because black carbon is released by incomplete combustion of biomass [75], and it was employed here to illustrate its presence over the fire-affected area.

\subsection{Wind Data}

We also used MERRA-2 3-hourly averaged surface wind speed data $(\mathrm{m} / \mathrm{s})$ at $0.5^{\circ} \times 0.625^{\circ}$ grid-level, from 26 October to 29 October 2018. This was used to depict wind conditions over the study area.

\subsection{Reference Data}

We identified 150 samples for each burned and unburned class from the high-resolution CNES/Airbus satellite imagery available from Google Earth Pro. The imagery was acquired on 12 December 2018 - few days after the fire incident in the studied area. Burned patches were clearly distinct from unburned vegetation, and a historical imagery function was used to verify vegetation conditions. The samples were randomly distributed throughout the fire zone. Sample layers were converted from the keyhole markup language to shapefile format in the Environmental Systems Research Institute (ESRI) ArcMap environment and later imported to GEE for classification, as shown in Figure 2. 


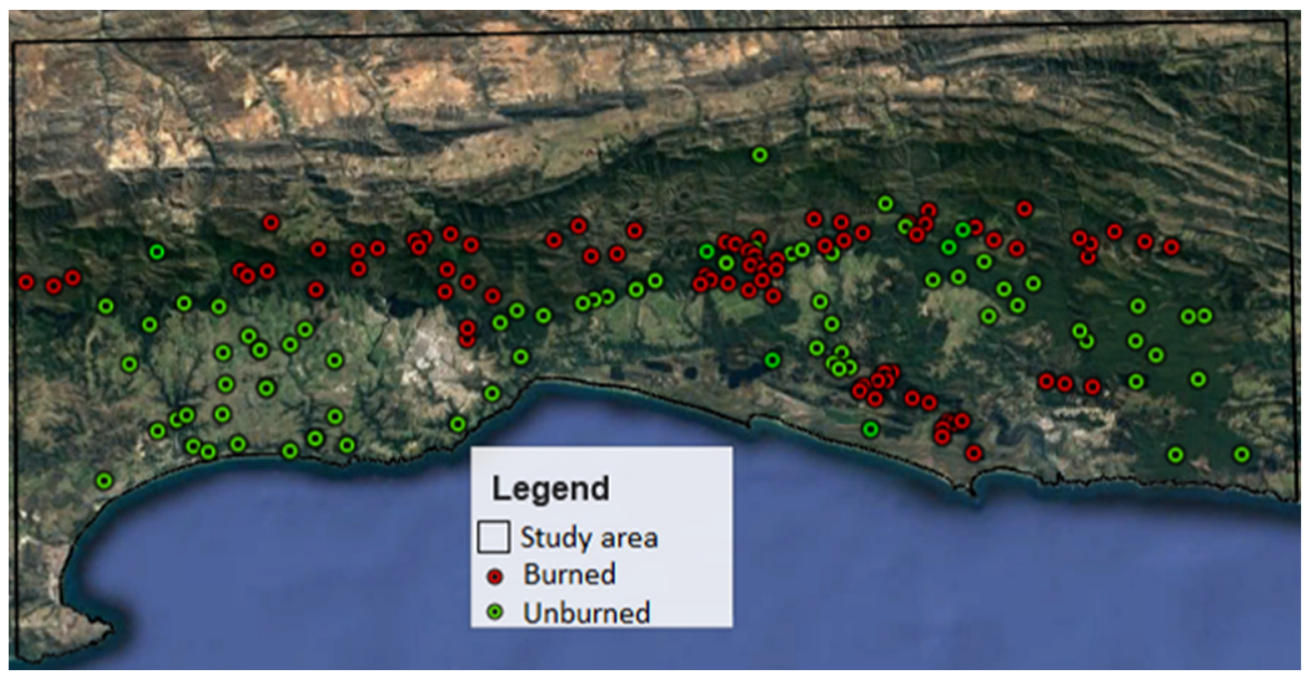

Figure 2. Spatial distribution of samples for burned and unburned areas.

\subsection{Random Forests Classification, Validation and Variable Contribution}

The accuracy of a classifier entails the probability that it will correctly classify a random set of examples [76], in our case, burned and unburned classes. The classification of burned and unburned classes was performed using the Random Forests (RF; Breiman [77]) algorithm available in the GEE platform. The choice for RF algorithm application in this is influenced by its success and extensive use in burned area valuation studies [54]. RF uses ensemble methods with multiple tree-type classifiers to attain better predictions and it builds a perfect forest of random uncorrelated DTs to achieve the best possible result [77]. The number of trees was set to 30 , while the number of predictor variables at each node was set at the square root of the input variables used in the model [78], which is 4 in our case. Certainly, some spectral bands/ratios are more important than others for the classification, and it was established that when more spectral bands are included, the accuracy is improved until a certain threshold is reached [79]. Here, we used 16 input variables, which included Sentinel-2 bands excluding aerosol and water vapor bands displayed in Table 2, NBR, NDVI, NDWI, NDWI1, and texture. The aerosol and water vapor bands were excluded because of their irrelevance to burnt area mapping [80]. We followed Nomura and Mitchard [81] by incorporating a texture index in the classification because it is known to increase accuracy [82], in our case, this was computed from the standard deviation of NBR. The samples were randomly divided into $70 \%$ for training the classifier and $30 \%$ for validating datasets. The procedure was reiterated 1000 times and the proportion of correctly classified entries in the validation dataset was documented using the overall classification accuracy.

Table 2. Spectral bands of the Sentinel-2 imagery.

\begin{tabular}{cccc}
\hline Spectral Band & Band Name & Wavelength & $\begin{array}{c}\text { Spatial } \\
\text { Resolution (m) }\end{array}$ \\
\hline B1 & Coastal aerosol & $442.3-443.9 \mathrm{~nm}$ & 60 \\
B2 & Blue & $492.1-496.6 \mathrm{~nm}$ & 10 \\
B3 & Green & $559-560 \mathrm{~nm}$ & 10 \\
B4 & Red & $664.5-665 \mathrm{~nm}$ & 10 \\
B5 & Red edge 1 & $703.8-703.9 \mathrm{~nm}$ & 20 \\
B6 & Red edge 2 & $739.1-740.2 \mathrm{~nm}$ & 20 \\
B7 & Red edge 3 & $779.7-782.5 \mathrm{~nm}$ & 20 \\
B8 & NIR & $833-835.1 \mathrm{~nm}$ & 10 \\
B8A & Near infrared narrow & $864-864.8 \mathrm{~nm}$ & 20 \\
B9 & Water vapor & $943.2-945 \mathrm{~nm}$ & 60 \\
B10 & SWIR cirrus & $1376.9-1373.5 \mathrm{~nm}$ & 60 \\
B11 & SWIR 1 & $1610.4-1613.7 \mathrm{~nm}$ & 20 \\
B12 & SWIR 2 & $2185.7-2202.4 \mathrm{~nm}$ & 20 \\
\hline
\end{tabular}


We also performed the RF variable importance within the GEE environment to find the spectral bands and ratios that mostly contributed to the overall burned area classification. We used the decrease in node impurities measured by the Gini index for this purpose. The variable with the highest Gini index was considered the most important compared to the other input variables in the Sentinel-2 imagery.

\section{Results and Discussion}

\subsection{Burned Area Mapping}

Figure 3 shows a burned area from Sentinel-2 imagery; (a) pre-fire image, (b) post-fire image and (c) the spatial distribution of burned area detected in the study area using NBR. The burn scars in the post-fire image are clearly noticeable. Burned areas are characterized by residues of charcoal and ash, removal of vegetation, and modification of the vegetation structure [83].

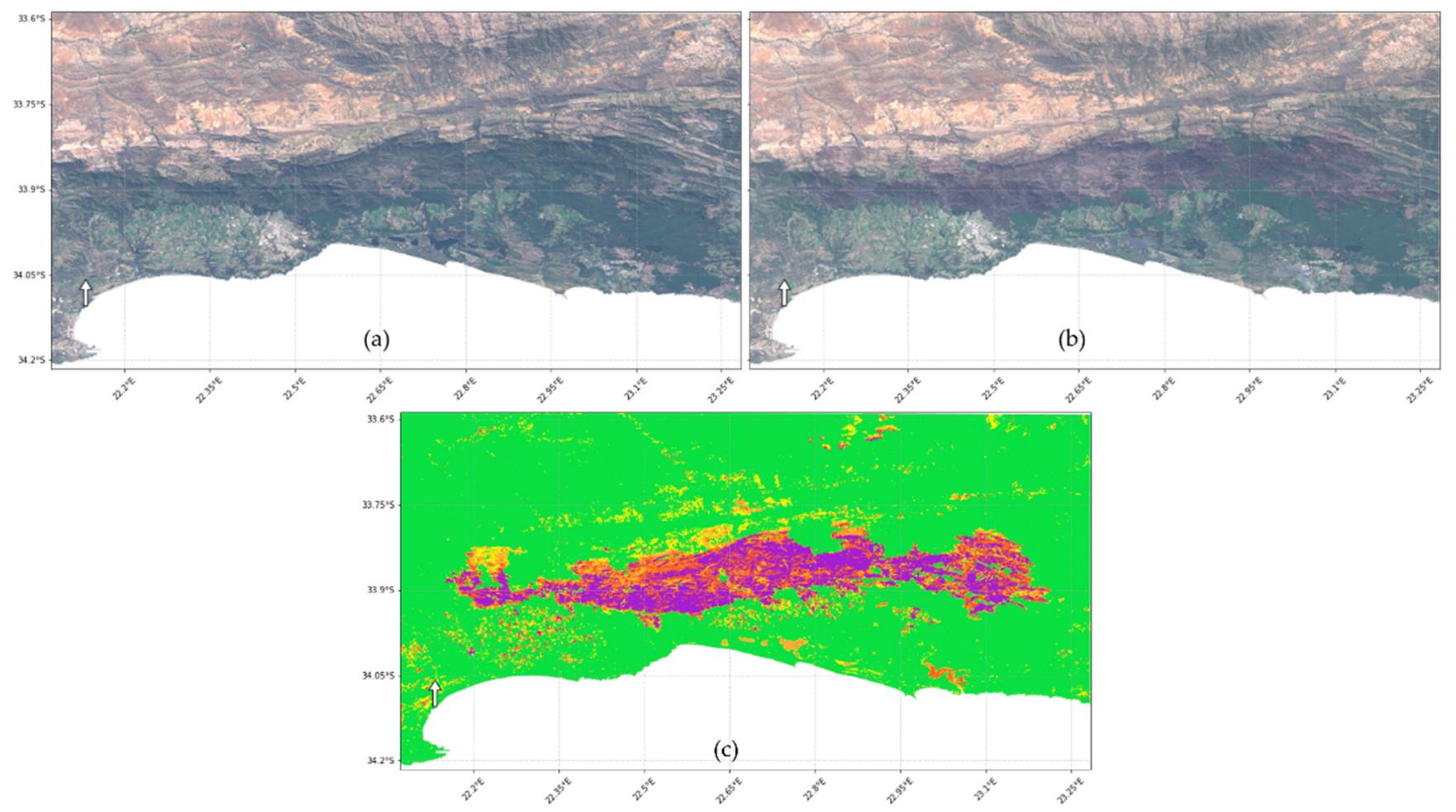

Figure 3. Burned area mapping with Sentinel-2; (a) pre-fire image; (b) post-fire image; (c) detected burned areas in the study area.

\subsection{Burned Severity Analysis}

The areal extent of the burned area over the study area is presented in Table 3 and had a definite yet relatively simple configuration (Figure 4). As shown in Table 3, almost two-thirds (90,551 ha) of the study area was highly burned, with high and moderatehigh categories accounting for $37.4 \%$ and $24.7 \%$, respectively; much of this is spatially concentrated in the central interior where forested lands are dominant. The remaining 55,322 ha was slightly burned, with $15.9 \%$ for the moderate-low category and $21.9 \%$ for the low. These classes showed a patchy distribution spread across the study area. 
Table 3. Proportion of burned areas by severity class.

\begin{tabular}{ccc}
\hline Severity Level & Burned Area (ha) & Percentage \\
\hline High & 54,583 & 37.4 \\
Moderate-high & 35,968 & 24.7 \\
Moderate-low & 23,299 & 15.9 \\
Low & 32,023 & 21.9 \\
Total & 145,873 & 100 \\
\hline
\end{tabular}

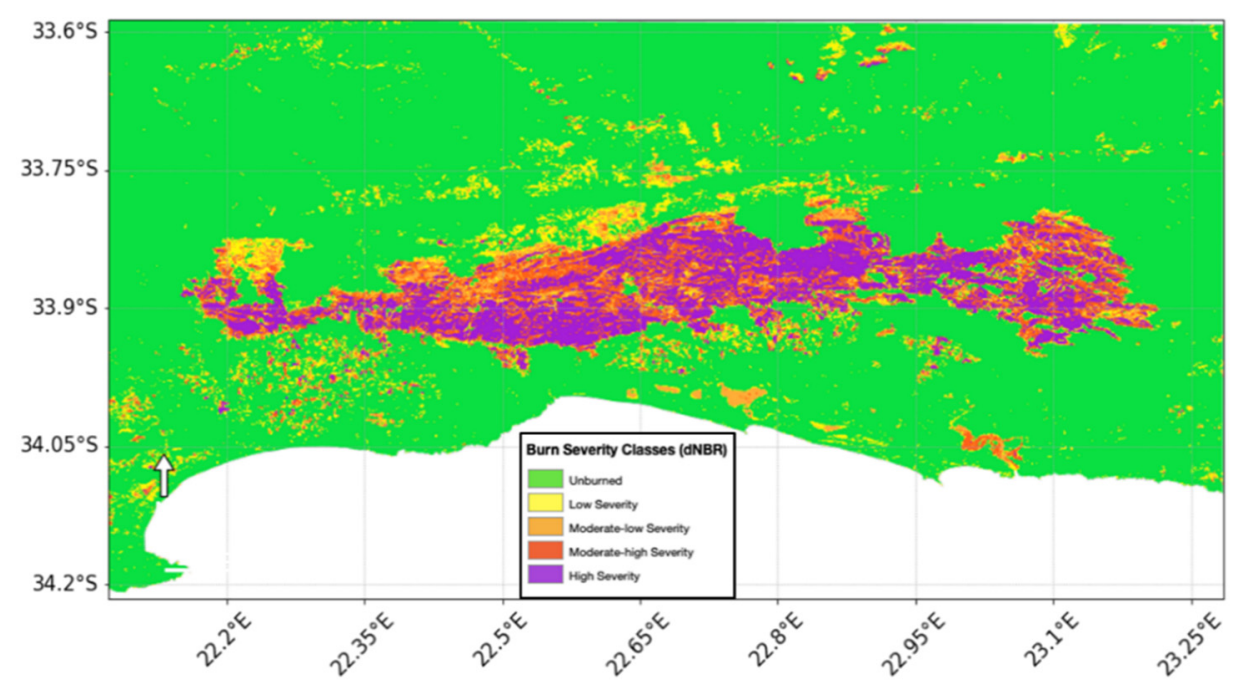

Figure 4. Spatial distribution of burned area by severity class.

\subsection{Burned Area by Land-Use/Land Cover Class}

The studied fire affected five dominant land use/land cover classes, and the results are illustrated in Figure 5. A large burned area occurred within the forested area (53.4\%), most of which were natural forests $(35.4 \%)$ and $18.0 \%$ comprising commercial planted forest. This was followed by the grasses and shrubs category with $24.4 \%$, while cultivated land represents $21.1 \%$ of the burned area. The smallest class is that of wetlands with $1.1 \%$.

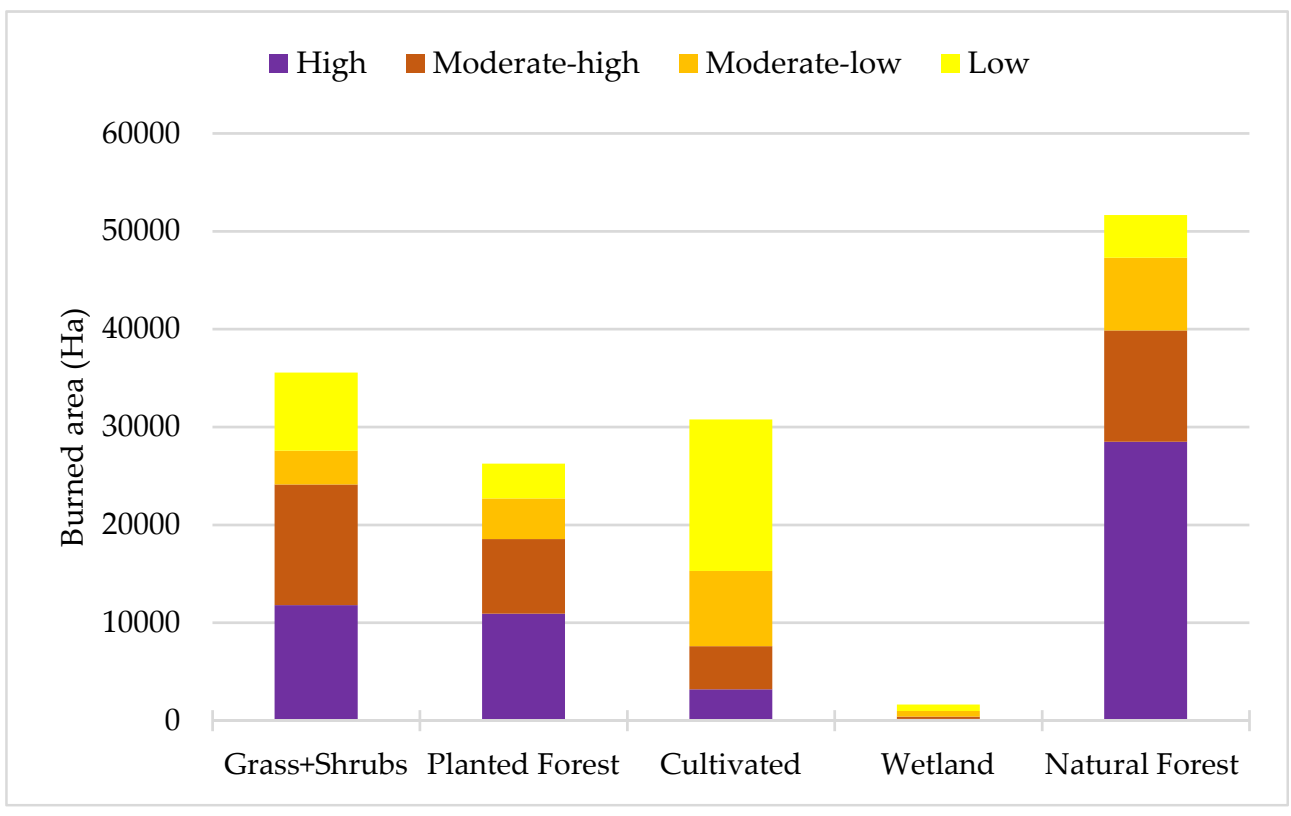

Figure 5. Burned area by land-use/land cover class. 
Different terrain conditions are displayed in Figure 6. Figure 6a,b show the smoke over planted forests during the fire incident, which claimed eight lives in a forest village and destroying several structures, including the Sawmill (Figure 6d) [26].
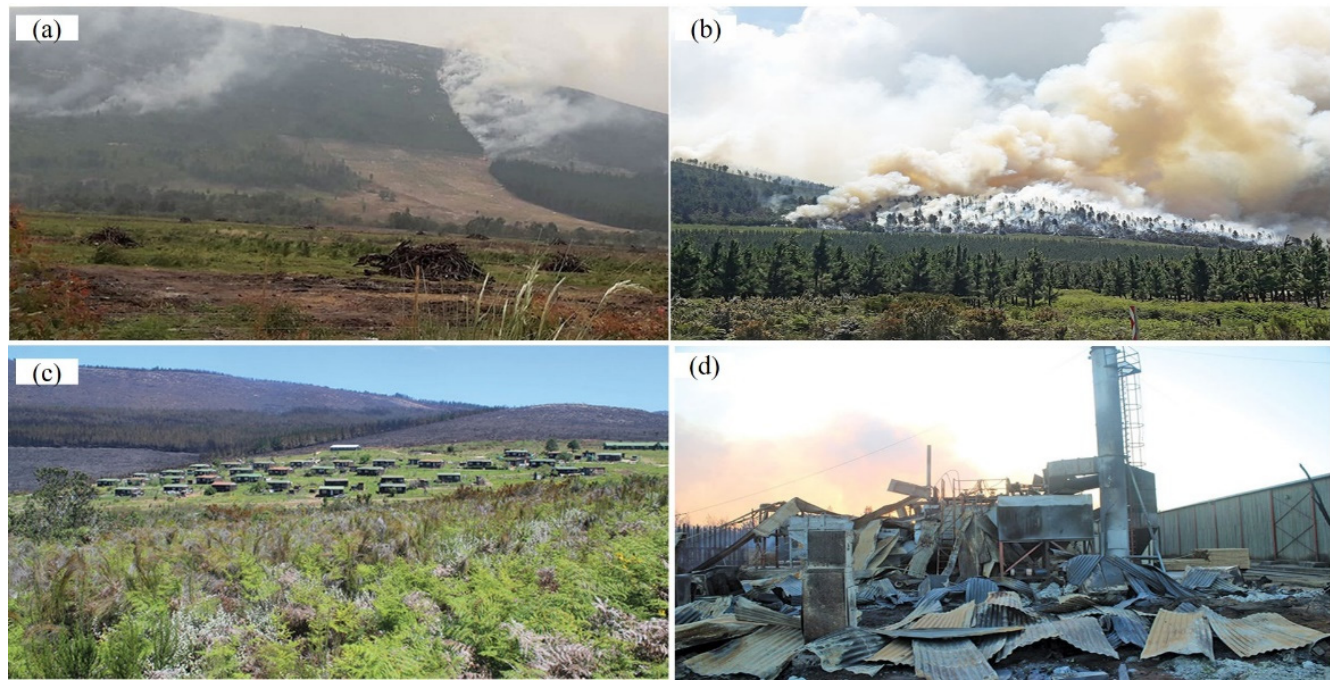

(d)

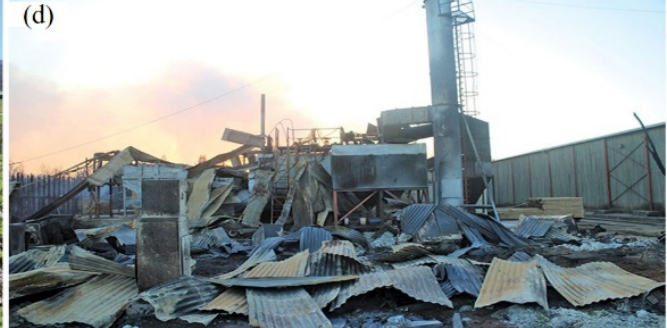

Figure 6. Burn severities in various terrain conditions; (a); Fire smoke recorded during fire event with young plantations in 2018 (b) Active fire plume; (c) Village adjacent to forest affected by fire; (d) Sawmill damaged by fire. (SA Forestry [26,27]).

\section{4. $C O, B C$ and Wind Analysis}

We elaborate here on the above analyses by demonstrating the capability of Sentinel to track fire-generated products such as carbon monoxide. In this case, fires were observed using Sentinel-2 and CO emissions through the recently launched Sentinel-5, which carries TROPOMI.

Fires burning in the plantation forests in the southern Cape, as captured by Sentinel-2 imagery on 12 October 2018, are shown in Figure 7). The exploitation of SWIR, NIR and the red bands make it possible to detect active fires and the resultant smoke plume rising into the atmosphere, as can be seen from Figure 7a. The Sentinel-2 imagery was captured during the occurrence of this fire event; otherwise, this sensors' 5-day temporal cycle may limit the detection of active fires. As previously stated, all currently obtainable active fire detection products are derived from coarse spatial-resolution sensors of not less than $250 \mathrm{~m}$, presenting a serious challenge for detecting smaller fires [84]. Such fires are often less damaging than bigger ones, but they still contribute to ecological and atmospheric dynamics [42]. In agreement with Roteta et al. [84], Sentinel-2 fine-scale product would assuredly enhance the amount of the total burned area, when cloud detection as the major source of commission errors was improved.

Forest fires emit several products of combustion into the atmosphere including trace gases such as $\mathrm{CO}$ [85]. In this regard, the $\mathrm{CO}$ column density during the study period was mapped over South Africa using Sentinel-5 with the results displayed in Figure $7 \mathrm{~b}$. The figure shows that the $\mathrm{CO}$ concentrations were highest over the study area, with small red patches scattered across the country and medium-low to medium-high (yellow/purple) densities recorded in the northeastern parts. The time series of $\mathrm{CO}$ column density, which narrowed over the study area from 5 July 2018 to 20 May 2020, is displayed in Figure 7c. During this period, $\mathrm{CO}$ had a column density averaging $0.023 \mathrm{~mol} / \mathrm{m}^{-2}$. The exceptional increase in CO from $0.038 \mathrm{~mol} / \mathrm{m}^{-2}$ on 26 October 2018 to $0.083 \mathrm{~mol} / \mathrm{m}^{-2}$ on 27 October, and peaking at $0.098 \mathrm{~mol} / \mathrm{m}^{-2}$ on 28 October, coincides with a prominent fire that consumed many hectares of plantation forest in this area. Again, a marked increase in CO from $0.054 \mathrm{~mol} / \mathrm{m}^{-2}$ on 2 November 2018 to $0.094 \mathrm{~mol} / \mathrm{m}^{-2}$ on 3 November 2018 is noted. 
These patterns are consistent with fire events in succession, first in late October and the second at the beginning of November [26]. This means that there is a lag time of 2 days.

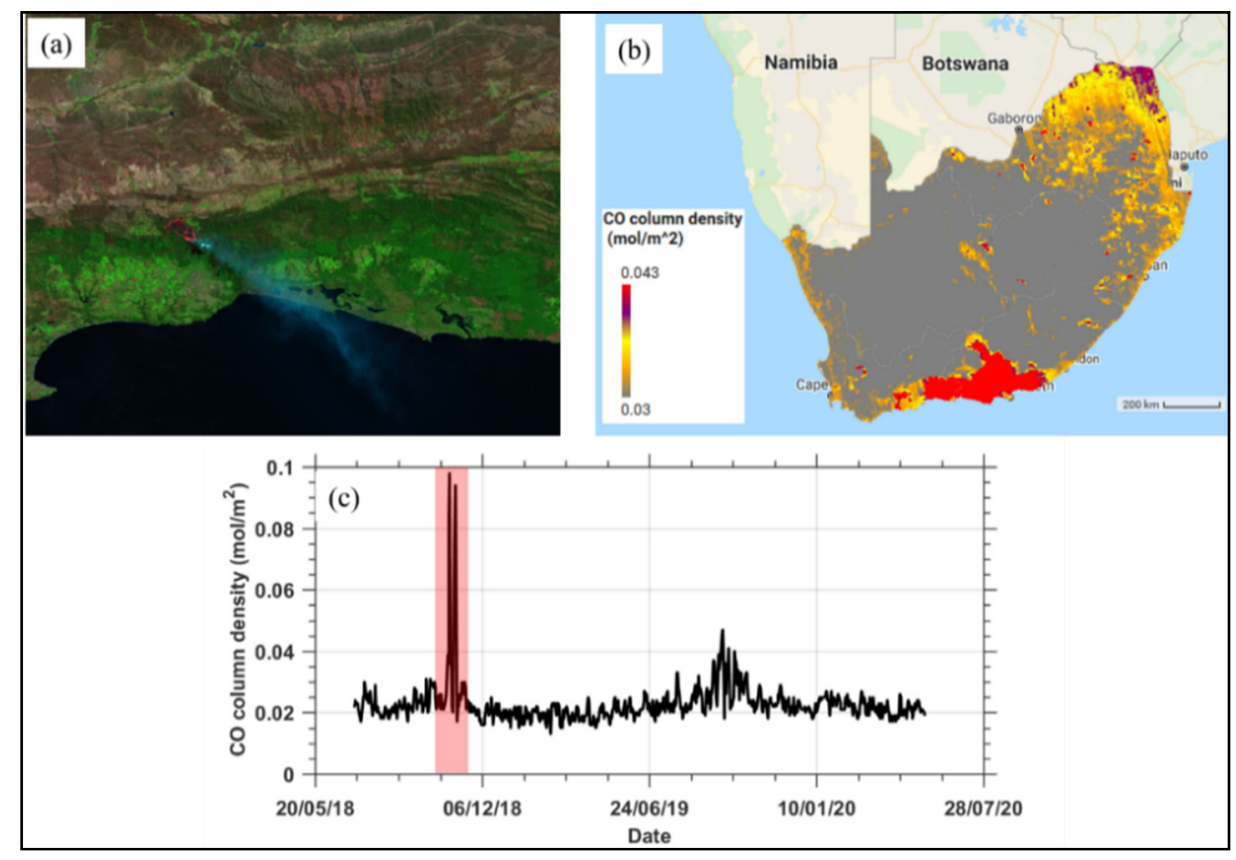

Figure 7. (a) The forest fire burning in the Witfontein Plantation during October-November 2018 as recorded by the Sentinel-2 satellite; (b) Carbon Monoxide column density as measured by Sentinel-5; (c) daily Carbon Monoxide column density over the study area between 5 July 2018 and 20 May 2020.

We extended the above analysis by analyzing black carbon as well as surface wind speed over the fire-affected region, and the results are shown in Figure 8. The surface winds were used to identify the dispersion direction of the biomass burning plume produced by the fire event. The observations show that there are higher concentrations of $\mathrm{BC}$ $\left(1.6 \times 10^{-8} \mathrm{~kg} / \mathrm{m}^{3}\right)$ that decrease from the central burned area over the southern Cape (see Figure 8a). This observation corroborates CO column density captured by the Sentinel-5 as displayed in Figure $7 \mathrm{~b}$ above. Wind speed appears to be stronger from sideways but weakens towards the studied area, converging southwards. Our findings are consistent with FSA [26] in that extreme winds with gusts of up to $100 \mathrm{~km} / \mathrm{h}$ raged some areas of the Garden Route, while areas around George had weaker winds (Figure 8b). This implies that the fire plume persisted over the affected area and slowly dispersed towards the coast.

\subsection{Accuracy Assessment}

We classified burned and unburned areas using RF, and the results are displayed in Table 4. Accuracy levels per class were consistently high for both burned and unburned classes, with producer accuracy of $98 \%$ to $97 \%$ and user accuracy of $97 \%$ and $98 \%$, respectively (Table 4). The RF achieved an overall accuracy of $98 \%$. These results are comparable with Seydi et al. [55], who detected burned areas with accuracies ranging from $82 \%$ to $91 \%$ within the GEE environment. 


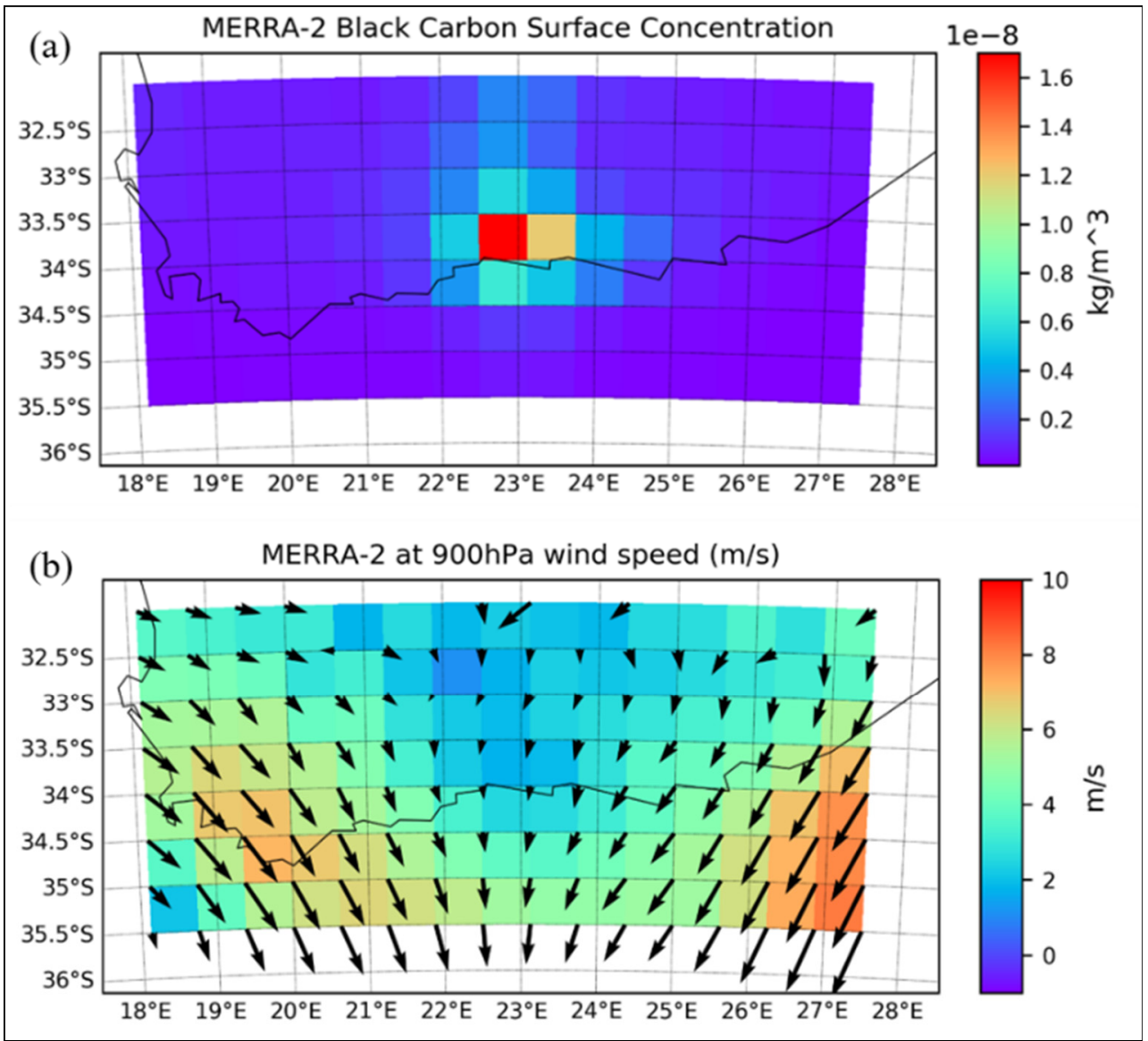

Figure 8. (a) Black carbon surface concentration and (b) Surface wind speed averaged 3-hourly over the Southern Cape from 26-29 October 2018.

Table 4. Accuracy assessments for burned and unburned classes.

\begin{tabular}{ccccc}
\hline \multicolumn{2}{c}{ Producer's Accuracy (\%) } & \multicolumn{2}{c}{ User's Accuracy $(\%)$} & \multicolumn{2}{c}{ Overall } \\
Burned & Unburned & Burned & Unburned & Accuracy (\%) \\
\hline 98 & 97 & 97 & 98 & 98 \\
\hline
\end{tabular}

\subsection{Variable Contribution}

On detecting burned areas using Sentinel-2, the RF variable importance exercise identified texture, NBR and NIR as variables that contributed most to the overall burned area classification (Figure 9).

In summary, we presented a quick and affordable approach for monitoring burned areas within a GEE platform. The GEE offered a convenient environment for classifying burned areas and also facilitated the identification of variables that contributed most to burned area detection when using Sentinel-2. Our results successfully showed potential for GEE resources to estimate burned land use/cover classes with great fidelity. This is comparable to Seydi et al. [55], who quantified burned classed using the same platform. The mapping of forest fires contributes a major component of forest fire management, and the rich information recorded by Sentinel's constellation of sensors allows muchimproved characterization and identification of forest fires than previously, particularly when implemented in the GEE environment, which can be easily accessed and adjusted to select dates that best suit the ecosystem of interest. The methodology reported here may be readily replicated through time and can be used for other agricultural activities prone 
to fire damage. Moreover, this methodology holds much promise for the South African government to estimate burned land use/cover classes with greater accuracy.

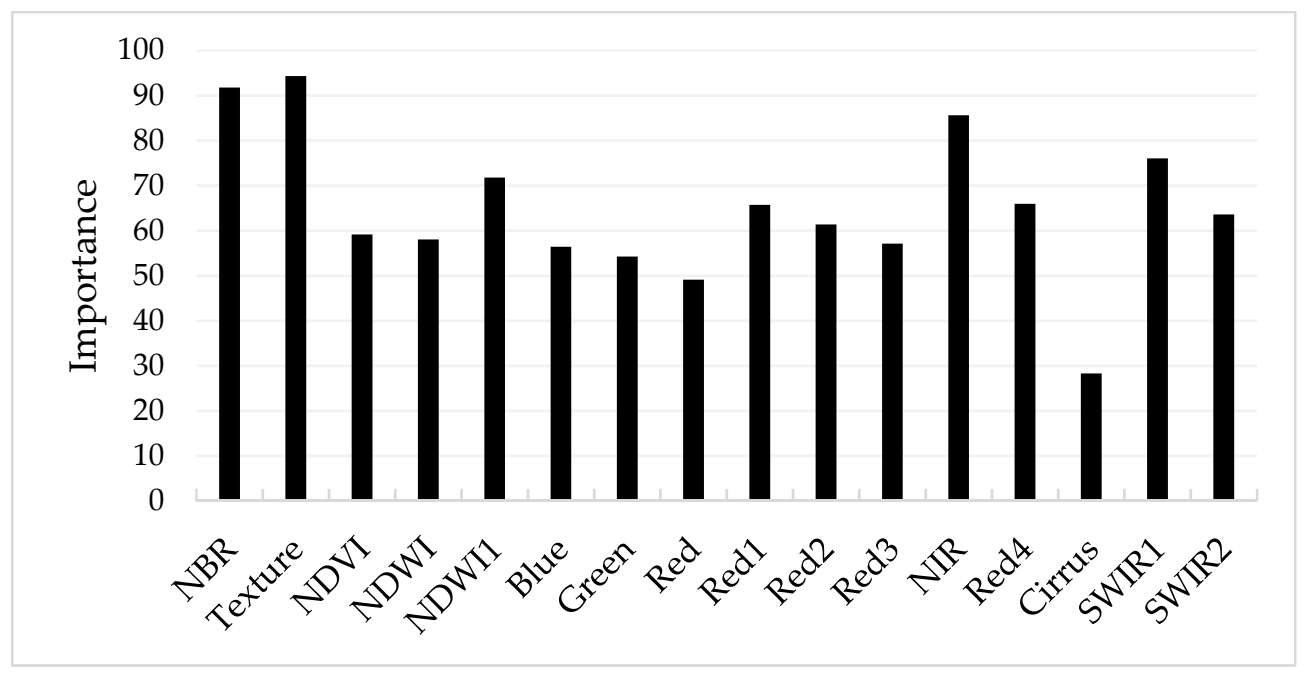

Figure 9. The importance of each variable in burned area mapping.

\section{Conclusions}

The results in this study demonstrate the great potential of freely available Sentinel2 satellite data and the respective derived ratios to map fire damage in the fire-prone landscape of the Southern Cape in South Africa. Using the differenced normalized burned ratio (dNBR) derived from Sentinel-2, we successfully tracked the extent of burned areas and the corresponding severity of the damage to the vegetation that succumbed to fire with accuracies exceeding $97 \%$ based on RF. The RF also identified texture, NBR, and NIR as the most important variables in the classification. The forested area was the most affected class. We also analyzed the pattern of carbon monoxide (CO) plumes recorded by Sentinel-5, with a marked peak during the fire incident. Most of the region was accounted for by forestry, whereas the remainder of the area represented the fynbos biome. Overall, $\mathrm{CO}$ was a reliable indicator for tracking fires and can be used in combination with remotely derived vegetation indices for a national fire assessment and monitoring framework. Moreover, our study reaffirmed the GEE-based tools as efficient resources in facilitating the rapid generation of burned area outputs.

Author Contributions: Conceptualization, Sifiso Xulu and Nkanyiso Mbatha; methodology, Sifiso Xulu and Nkanyiso Mbatha; validation, Sifiso Xulu and Nkanyiso Mbatha; formal analysis, Sifiso Xulu, Nkanyiso Mbatha and Kabir Peerbhay; investigation, Sifiso Xulu and Nkanyiso Mbatha; resources, Sifiso Xulu and Nkanyiso Mbatha; data curation, Sifiso Xulu and Nkanyiso Mbatha; writing - original draft preparation Sifiso Xulu, Nkanyiso Mbatha and Kabir Peerbhay; writingreview and editing, Sifiso Xulu, Nkanyiso Mbatha and Kabir Peerbhay; visualization, Sifiso Xulu and Nkanyiso Mbatha; funding acquisition, Kabir Peerbhay. All authors have read and agreed to the published version of the manuscript.

Funding: This research was funded by the National Research Foundation (NRF) of South Africa (Grant number: 114898).

Data Availability Statement: The datasets used and/or analyzed in this study are available from the corresponding author on reasonable request.

Acknowledgments: The authors are thankful to Graham Baker for manuscript editing and proofreading and to the anonymous reviewers and editors for their invaluable comments and suggestions, which have improved the quality of the manuscript. The authors are also thankful to Keiko Nomura for her support with the GEE scripting and the Google Earth Engine Team for the GEE cloud platform. The authors would also like to thank three anonymous reviewers for their valuable comments and suggestions. 
Conflicts of Interest: The authors declare no conflict of interest.

\section{References}

1. Lottering, R.; Mutanga, O.; Peerbhay, K. Detecting and Mapping Levels of Gonipterus Scutellatus-Induced Vegetation Defoliation and Leaf Area Index Using Spatially Optimized Vegetation Indices. Geocarto Int. 2018, 33, 277-292. [CrossRef]

2. Poona, N.K.; Ismail, R. Discriminating the Occurrence of Pitch Canker Fungus in Pinus Radiata Trees Using QuickBird Imagery and Artificial Neural Networks. South. For. J. For. Sci. 2013, 75, 29-40. [CrossRef]

3. Peerbhay, K.; Mutanga, O.; Lottering, R.; Ismail, R. Mapping Solanum Mauritianum Plant Invasions Using WorldView-2 Imagery and Unsupervised Random Forests. Remote Sens. Environ. 2016, 182, 39-48. [CrossRef]

4. Xulu, S.; Peerbhay, K.; Gebreslasie, M.; Ismail, R. Drought Influence on Forest Plantations in Zululand, South Africa, Using MODIS Time Series and Climate Data. Forests 2018, 9, 528. [CrossRef]

5. DAFF (Department of Agriculture, Forestry and Fisheries). Report on Commercial Timber Resources and Primary Roundwood Processing in South Africa-2010/2011; Directorate, Forestry Regulation and Oversight: Pretoria, South Africa, 2011.

6. Forsyth, G.; Le Maitre, D.; Van den Dool, R.; Walls, R.; Pharoah, R.; Fortune, G. The Knysna Fires of 2017: Learning from This Disaster; CSIR, Stellenbosch University and Santam: Stellenbosch, South Africa, 2019.

7. Sommers, W.T.; Loehman, R.A.; Hardy, C.C. Wildland Fire Emissions, Carbon, and Climate: Science Overview and Knowledge Needs. For. Ecol. Manag. 2014, 317, 1-8. [CrossRef]

8. Vilà, M.; Lloret, F.; Ogheri, E.; Terradas, J. Positive Fire-Grass Feedback in Mediterranean Basin Woodlands. For. Ecol. Manag. 2001, 147, 3-14. [CrossRef]

9. Hislop, S.; Jones, S.; Soto-Berelov, M.; Skidmore, A.; Haywood, A.; Nguyen, T.H. Using Landsat Spectral Indices in Time-Series to Assess Wildfire Disturbance and Recovery. Remote Sens. 2018, 10, 460. [CrossRef]

10. Alkhatib, A.A. A Review on Forest Fire Detection Techniques. Int. J. Distrib. Sens. Netw. 2014, 10, 597368. [CrossRef]

11. Chuvieco, E.; Aguado, I.; Yebra, M.; Nieto, H.; Salas, J.; Martín, M.P.; Vilar, L.; Martínez, J.; Martín, S.; Ibarra, P. Development of a Framework for Fire Risk Assessment Using Remote Sensing and Geographic Information System Technologies. Ecol. Model. 2010, 221, 46-58. [CrossRef]

12. Avila-Flores, D.; Pompa-Garcia, M.; Antonio-Nemiga, X.; Rodriguez-Trejo, D.A.; Vargas-Perez, E.; Santillan-Perez, J. Driving Factors for Forest Fire Occurrence in Durango State of Mexico: A Geospatial Perspective. Chin. Geogr. Sci. 2010, 20, 491-497. [CrossRef]

13. Stephens, S.L.; Collins, B.M.; Fettig, C.J.; Finney, M.A.; Hoffman, C.M.; Knapp, E.E.; North, M.P.; Safford, H.; Wayman, R.B. Drought, Tree Mortality, and Wildfire in Forests Adapted to Frequent Fire. BioScience. 2018, 68, 77-88. [CrossRef]

14. Keeley, J.E.; Syphard, A.D. Different Historical Fire-Climate Patterns in California. Int. J. Wildland Fire 2017, $26,253-268$. [CrossRef]

15. Geldenhuys, C.J. Bergwind Fires and the Location Pattern of Forest Patches in the Southern Cape Landscape, South Africa. J. Biogeogr. 1994, 49-62. [CrossRef]

16. Yocom, L.L.; Fulé, P.Z.; Brown, P.M.; Cerano, J.; Villanueva-Díaz, J.; Falk, D.A.; Cornejo-Oviedo, E. El Niño-Southern Oscillation Effect on a Fire Regime in Northeastern Mexico Has Changed over Time. Ecology. 2010, 91, 1660-1671. [CrossRef] [PubMed]

17. Nogueira, J.M.; Rambal, S.; Barbosa, J.P.R.; Mouillot, F. Spatial Pattern of the Seasonal Drought/Burned Area Relationship across Brazilian Biomes: Sensitivity to Drought Metrics and Global Remote-Sensing Fire Products. Climate 2017, 5, 42. [CrossRef]

18. Van Der Werf, G.R.; Randerson, J.T.; Collatz, G.J.; Giglio, L.; Kasibhatla, P.S.; Arellano, A.F.; Olsen, S.C.; Kasischke, E.S. Continental-Scale Partitioning of Fire Emissions during the 1997 to 2001 El Nino/La Nina Period. Science 2004, 303, 73-76. [CrossRef] [PubMed]

19. Westerling, A.L.; Hidalgo, H.G.; Cayan, D.R.; Swetnam, T.W. Warming and Earlier Spring Increase Western US Forest Wildfire Activity. Science 2006, 313, 940-943. [CrossRef] [PubMed]

20. Verhegghen, A.; Eva, H.; Ceccherini, G.; Achard, F.; Gond, V.; Gourlet-Fleury, S.; Cerutti, P.O. The Potential of Sentinel Satellites for Burnt Area Mapping and Monitoring in the Congo Basin Forests. Remote Sens. 2016, 8, 986. [CrossRef]

21. da Silva, S.S.; Fearnside, P.M.; de Alencastro Graça, P.M.L.; Brown, I.F.; Alencar, A.; de Melo, A.W.F. Dynamics of Forest Fires in the Southwestern Amazon. For. Ecol. Manag. 2018, 424, 312-322. [CrossRef]

22. Kraaij, T.; Baard, J.A.; Arndt, J.; Vhengani, L.; Van Wilgen, B.W. An Assessment of Climate, Weather, and Fuel Factors Influencing a Large, Destructive Wildfire in the Knysna Region, South Africa. Fire Ecol. 2018, 14, 4. [CrossRef]

23. Preston, G. Knysna Fires: Five Factors That Produced the Perfect Inferno; The Botanical Society of South Africa: Cape Town, South Africa, 2017.

24. Saidi, A.T.; Makhado, R.A. Disaster Risk Assessment at Roburnia Plantation, Mpumalanga, South Africa. Jàmbá J. Disaster Risk Stud. 2013, 5, 1-6.

25. Abdi, O.; Shirvani, Z.; Buchroithner, M.F. Spatiotemporal Drought Evaluation of Hyrcanian Deciduous Forests and Semi-Steppe Rangelands Using Moderate Resolution Imaging Spectroradiometer Time Series in Northeast Iran. Land Degrad. Dev. 2018, 29, 2525-2541. [CrossRef]

26. FSA (Forestry South Africa). Land of Smoke and Fire. 2018. Available online: http://saforestryonline.co.za/articles/land-ofsmoke-and-fire/ (accessed on 22 July 2020). 
27. FSA (Forestry South Africa). Garden Route Fires: Where to Now? 2018. Available online: http://saforestryonline.co.za/articles/ garden-route-fires-where-to-now / (accessed on 22 July 2020).

28. Forestry in South Africa. Forestry South Africa Timber Statistics Report-2016-2017. Available online: https://forestry.co.za/ timber-statistics-report-2016-2017/ (accessed on 10 May 2021).

29. Bobbe, T.; Finco, M.V.; Quayle, B.; Lannom, K.; Sohlberg, R.; Parsons, A. Field Measurements for the Training and Validation of Burn Severity Maps from Spaceborne, Remotely Sensed Imagery. USDI Joint. Fire Sci. Program Final Proj. Rep. JFSP RFP 2001, 2, $1-15$.

30. Badarinath, K.V.S.; Sharma, A.R.; Kharol, S.K. Forest Fire Monitoring and Burnt Area Mapping Using Satellite Data: A Study over the Forest Region of Kerala State, India. Int. J. Remote Sens. 2011, 32, 85-102. [CrossRef]

31. Hussin, Y.A.; Zagdaa, N. The Applications of Remote Sensing and GIS in Modeling Forest Fire Hazard in Mongolia. Available online: http:/ / www.isprs.org/proceedings/XXXVII/congress/8_pdf/2_WG-VIII-2/22.pdf (accessed on 10 March 2021).

32. Näsi, R.; Honkavaara, E.; Lyytikäinen-Saarenmaa, P.; Blomqvist, M.; Litkey, P.; Hakala, T.; Viljanen, N.; Kantola, T.; Tanhuanpää, T.; Holopainen, M. Using UAV-Based Photogrammetry and Hyperspectral Imaging for Mapping Bark Beetle Damage at Tree-Level. Remote Sens. 2015, 7, 15467-15493. [CrossRef]

33. Warner, T.A.; Skowronski, N.S.; Gallagher, M.R. High Spatial Resolution Burn Severity Mapping of the New Jersey Pine Barrens with WorldView-3 near-Infrared and Shortwave Infrared Imagery. Int. J. Remote Sens. 2017, 38, 598-616. [CrossRef]

34. Meng, R.; Wu, J.; Zhao, F.; Cook, B.D.; Hanavan, R.P.; Serbin, S.P. Measuring Short-Term Post-Fire Forest Recovery across a Burn Severity Gradient in a Mixed Pine-Oak Forest Using Multi-Sensor Remote Sensing Techniques. Remote Sens. Environ. 2018, 210, 282-296. [CrossRef]

35. Parks, S.A.; Holsinger, L.M.; Koontz, M.J.; Collins, L.; Whitman, E.; Parisien, M.-A.; Loehman, R.A.; Barnes, J.L.; Bourdon, J.-F.; Boucher, J. Giving Ecological Meaning to Satellite-Derived Fire Severity Metrics across North American Forests. Remote Sens. 2019, 11, 1735. [CrossRef]

36. Chen, X.; Vogelmann, J.E.; Rollins, M.; Ohlen, D.; Key, C.H.; Yang, L.; Huang, C.; Shi, H. Detecting Post-Fire Burn Severity and Vegetation Recovery Using Multitemporal Remote Sensing Spectral Indices and Field-Collected Composite Burn Index Data in a Ponderosa Pine Forest. Int. J. Remote Sens. 2011, 32, 7905-7927. [CrossRef]

37. Coppo, P. Simulation of Fire Detection by Infrared Imagers from Geostationary Satellites. Remote Sens. Environ. 2015, 162, 84-98. [CrossRef]

38. Mouillot, F.; Schultz, M.G.; Yue, C.; Cadule, P.; Tansey, K.; Ciais, P.; Chuvieco, E. Ten Years of Global Burned Area Products from Spaceborne Remote Sensing-A Review: Analysis of User Needs and Recommendations for Future Developments. Int. J. Appl. Earth Obs. Geoinf. 2014, 26, 64-79. [CrossRef]

39. Alonso-Canas, I.; Chuvieco, E. Global Burned Area Mapping from ENVISAT-MERIS and MODIS Active Fire Data. Remote Sens. Environ. 2015, 163, 140-152. [CrossRef]

40. Padilla, M.; Stehman, S.V.; Ramo, R.; Corti, D.; Hantson, S.; Oliva, P.; Alonso-Canas, I.; Bradley, A.V.; Tansey, K.; Mota, B. Comparing the Accuracies of Remote Sensing Global Burned Area Products Using Stratified Random Sampling and Estimation. Remote Sens. Environ. 2015, 160, 114-121. [CrossRef]

41. Chuvieco, E.; Mouillot, F.; van der Werf, G.R.; San Miguel, J.; Tanase, M.; Koutsias, N.; García, M.; Yebra, M.; Padilla, M.; Gitas, I. Historical Background and Current Developments for Mapping Burned Area from Satellite Earth Observation. Remote Sens. Environ. 2019, 225, 45-64. [CrossRef]

42. Hantson, S.; Padilla, M.; Corti, D.; Chuvieco, E. Strengths and Weaknesses of MODIS Hotspots to Characterize Global Fire Occurrence. Remote Sens. Environ. 2013, 131, 152-159. [CrossRef]

43. Eva, H.; Lambin, E.F. Fires and Land-Cover Change in the Tropics: A Remote Sensing Analysis at the Landscape Scale. J. Biogeogr. 2000, 27, 765-776. [CrossRef]

44. Chuvieco, E. Measuring Changes in Landscape Pattern from Satellite Images: Short-Term Effects of Fire on Spatial Diversity. Int. J. Remote Sens. 1999, 20, 2331-2346. [CrossRef]

45. Mithal, V.; Nayak, G.; Khandelwal, A.; Kumar, V.; Nemani, R.; Oza, N.C. Mapping Burned Areas in Tropical Forests Using a Novel Machine Learning Framework. Remote Sens. 2018, 10, 69. [CrossRef]

46. Stavrakoudis, D.; Katagis, T.; Minakou, C.; Gitas, I.Z. Towards a Fully Automatic Processing Chain for Operationally Mapping Burned Areas Countrywide Exploiting Sentinel-2 Imagery. In Proceedings of the Seventh International Conference on Remote Sensing and Geoinformation of the Environment (RSCy2019), Paphos, Cyprus, 18-21 March 2019; Volume 11174, p. 1117405.

47. Pádua, L.; Guimarães, N.; Adão, T.; Sousa, A.; Peres, E.; Sousa, J.J. Effectiveness of Sentinel-2 in Multi-Temporal Post-Fire Monitoring When Compared with UAV Imagery. ISPRS Int. J. Geo-Inf. 2020, 9, 225. [CrossRef]

48. Fan, C.; Li, Y.; Guang, J.; Li, Z.; Elnashar, A.; Allam, M.; de Leeuw, G. The Impact of the Control Measures during the COVID-19 Outbreak on Air Pollution in China. Remote Sens. 2020, 12, 1613. [CrossRef]

49. Gorelick, N.; Hancher, M.; Dixon, M.; Ilyushchenko, S.; Thau, D.; Moore, R. Google Earth Engine: Planetary-Scale Geospatial Analysis for Everyone. Remote Sens. Environ. 2017, 202, 18-27. [CrossRef]

50. Huntington, J.L.; Hegewisch, K.C.; Daudert, B.; Morton, C.G.; Abatzoglou, J.T.; McEvoy, D.J.; Erickson, T. Climate Engine: Cloud Computing and Visualization of Climate and Remote Sensing Data for Advanced Natural Resource Monitoring and Process Understanding. Bull. Am. Meteorol. Soc. 2017, 98, 2397-2410. [CrossRef] 
51. Tamiminia, H.; Salehi, B.; Mahdianpari, M.; Quackenbush, L.; Adeli, S.; Brisco, B. Google Earth Engine for Geo-Big Data Applications: A Meta-Analysis and Systematic Review. ISPRS J. Photogramm. Remote Sens. 2020, 164, 152-170. [CrossRef]

52. Kumar, L.; Mutanga, O. Google Earth Engine Applications since Inception: Usage, Trends, and Potential. Remote Sens. 2018, 10, 1509. [CrossRef]

53. Konkathi, P.; Shetty, A. Inter Comparison of Post-Fire Burn Severity Indices of Landsat-8 and Sentinel-2 Imagery Using Google Earth Engine. Earth Sci. Inform. 2021, 14, 645-653.

54. Bar, S.; Parida, B.R.; Pandey, A.C. Landsat-8 and Sentinel-2 Based Forest Fire Burn Area Mapping Using Machine Learning Algorithms on GEE Cloud Platform over Uttarakhand, Western Himalaya. Remote Sens. Appl. Soc. Environ. 2020, 18, 100324. [CrossRef]

55. Seydi, S.T.; Akhoondzadeh, M.; Amani, M.; Mahdavi, S. Wildfire Damage Assessment over Australia Using Sentinel-2 Imagery and MODIS Land Cover Product within the Google Earth Engine Cloud Platform. Remote Sens. 2021, 13, 220. [CrossRef]

56. Barboza Castillo, E.; Turpo Cayo, E.Y.; de Almeida, C.M.; Salas López, R.; Rojas Briceño, N.B.; Silva López, J.O.; Barrena Gurbillón, M.Á.; Oliva, M.; Espinoza-Villar, R. Monitoring Wildfires in the Northeastern Peruvian Amazon Using Landsat-8 and Sentinel-2 Imagery in the GEE Platform. ISPRS Int. J. Geo-Inf. 2020, 9, 564. [CrossRef]

57. Praticò, S.; Solano, F.; Di Fazio, S.; Modica, G. Machine Learning Classification of Mediterranean Forest Habitats in Google Earth Engine Based on Seasonal Sentinel-2 Time-Series and Input Image Composition Optimisation. Remote Sens. 2021, 13, 586. [CrossRef]

58. Puletti, N.; Chianucci, F.; Castaldi, C. Use of Sentinel-2 for Forest Classification in Mediterranean Environments. Ann. Silvic. Res 2017, 42, 32-38.

59. Filipponi, F. Exploitation of Sentinel-2 Time Series to Map Burned Areas at the National Level: A Case Study on the 2017 Italy Wildfires. Remote Sens. 2019, 11, 622. [CrossRef]

60. Dos Santos, S.M.B.; Bento-Gonçalves, A.; Franca-Rocha, W.; Baptista, G. Assessment of Burned Forest Area Severity and Postfire Regrowth in Chapada Diamantina National Park (Bahia, Brazil) Using DNBR and RdNBR Spectral Indices. Geosciences 2020, 10, 106. [CrossRef]

61. Key, C.H.; Benson, N.C. The Normalized Burn Ratio (NBR): A Landsat TM Radiometric Measure of Burn Severity; US Geological Survey Northern Rocky Mountain Science Center; U.S. Department of the Interior: Washington, DC, USA, 2003.

62. Keeley, J.E. Fire Intensity, Fire Severity and Burn Severity: A Brief Review and Suggested Usage. Int. J. Wildland Fire 2009, 18, 116-126. [CrossRef]

63. Parker, B.M.; Lewis, T.; Srivastava, S.K. Estimation and Evaluation of Multi-Decadal Fire Severity Patterns Using Landsat Sensors. Remote Sens. Environ. 2015, 170, 340-349. [CrossRef]

64. Key, C.H.; Benson, N.C. Landscape Assessment (LA). In FIREMON Fire Effects Monitoring and Inventory System; Gen Tech Rep RMRS-GTR-164-CD; Lutes, D.C., Keane, R.E., Caratti, J.F., Key, C.H., Benson, N.C., Sutherl, S., Gangi, L.J., Eds.; Department of Agriculture, Forest Service, Rocky Mountain Research Station: Fort Collins, CO, USA, 2006; Volume 164, p. LA-1-55.

65. Miller, J.D.; Thode, A.E. Quantifying Burn Severity in a Heterogeneous Landscape with a Relative Version of the Delta Normalized Burn Ratio (DNBR). Remote Sens. Environ. 2007, 109, 66-80. [CrossRef]

66. Teobaldo, D.; de Mello Baptista, G.M. Measurement of Severity of Fires and Loss of Carbon Forest Sink in the Conservation Units at Distrito Federal. Rev. Bras. Geogr. 2016, 9, 250-264. [CrossRef]

67. Escuin, S.; Navarro, R.; Fernandez, P. Fire Severity Assessment by Using NBR (Normalized Burn Ratio) and NDVI (Normalized Difference Vegetation Index) Derived from LANDSAT TM/ETM Images. Int. J. Remote Sens. 2008, 29, 1053-1073. [CrossRef]

68. Soverel, N.O.; Perrakis, D.D.; Coops, N.C. Estimating Burn Severity from Landsat DNBR and RdNBR Indices across Western Canada. Remote Sens. Environ. 2010, 114, 1896-1909. [CrossRef]

69. Kraaij, T.; Baard, J.A.; Cowling, R.M.; van Wilgen, B.W.; Das, S. Historical Fire Regimes in a Poorly Understood, Fire-Prone Ecosystem: Eastern Coastal Fynbos. Int. J. Wildland Fire. 2013, 22, 277-287. [CrossRef]

70. Kraaij, T.; van Wilgen, B.W. Drivers, Ecology, and Management of Fire in Fynbos. In Fynbos Ecology. Evolution and Conservation of a Megadiverse Region; Allsopp, N., Colville, J.F., Verboom, G.A., Eds.; Oxford University Press: Oxford, UK, $2014 ;$ pp. 47-72.

71. Kraaij, T.; Cowling, R.M.; Van Wilgen, B.W. Past Approaches and Future Challenges to the Management of Fire and Invasive Alien Plants in the New Garden Route National Park. South Afr. J. Sci. 2011, 107, 16-26. [CrossRef]

72. Tyson, P.D.; Preston-Whyte, R.A. Weather and Climate of Southern Africa; Oxford University Press: Oxford, UK, 2000.

73. Kleipool, Q.; Ludewig, A.; Babić, L.; Bartstra, R.; Braak, R.; Dierssen, W.; Dewitte, P.-J.; Kenter, P.; Landzaat, R.; Leloux, J. Pre-Launch Calibration Results of the TROPOMI Payload on-Board the Sentinel-5 Precursor Satellite. Atmos. Meas. Tech. 2018, 11, 6439-6479. [CrossRef]

74. Theys, N.; Hedelt, P.; De Smedt, I.; Lerot, C.; Yu, H.; Vlietinck, J.; Pedergnana, M.; Arellano, S.; Galle, B.; Fernandez, D. Global Monitoring of Volcanic SO 2 Degassing with Unprecedented Resolution from TROPOMI Onboard Sentinel-5 Precursor. Sci. Rep. 2019, 9, 1-10. [CrossRef] [PubMed]

75. Bond, T.C.; Streets, D.G.; Yarber, K.F.; Nelson, S.M.; Woo, J.-H.; Klimont, Z. A Technology-Based Global Inventory of Black and Organic Carbon Emissions from Combustion. J. Geophys. Res. Atmos. 2004, 109, 1-43. [CrossRef]

76. Kohavi, R. A Study of Cross-Validation and Bootstrap for Accuracy Estimation and Model Selection. In Proceedings of the 14th International Joint Conference on Artificial Intelligence (IJCAI), Montreal, QC, Canada, $20-25$ August 1995; Volume 14, pp. 1137-1145. 
77. Breiman, L. Random Forests. Mach. Learn. 2001, 45, 5-32. [CrossRef]

78. Gislason, P.O.; Benediktsson, J.A.; Sveinsson, J.R. Random Forests for Land Cover Classification. Pattern Recognit. Lett. 2006, 27, 294-300. [CrossRef]

79. Lee, J.S.H.; Wich, S.; Widayati, A.; Koh, L.P. Detecting Industrial Oil Palm Plantations on Landsat Images with Google Earth Engine. Remote Sens. Appl. Soc. Environ. 2016, 4, 219-224. [CrossRef]

80. Ngadze, F.; Mpakairi, K.S.; Kavhu, B.; Ndaimani, H.; Maremba, M.S. Exploring the Utility of Sentinel-2 MSI and Landsat 8 OLI in Burned Area Mapping for a Heterogenous Savannah Landscape. PLoS ONE. 2020, 15, e0232962. [CrossRef] [PubMed]

81. Nomura, K.; Mitchard, E.T. More than Meets the Eye: Using Sentinel-2 to Map Small Plantations in Complex Forest Landscapes. Remote Sens. 2018, 10, 1693. [CrossRef]

82. Feng, Q.; Liu, J.; Gong, J. UAV Remote Sensing for Urban Vegetation Mapping Using Random Forests and Texture Analysis. Remote Sens. 2015, 7, 1074-1094. [CrossRef]

83. Roy, D.P. Multi-Temporal Active-Fire Based Burn Scar Detection Algorithm. Int. J. Remote Sens. 1999, 20, 1031-1038. [CrossRef]

84. Roteta, E.; Bastarrika, A.; Padilla, M.; Storm, T.; Chuvieco, E. Development of a Sentinel-2 Burned Area Algorithm: Generation of a Small Fire Database for Sub-Saharan Africa. Remote Sens. Environ. 2019, 222, 1-17. [CrossRef]

85. Andreae, M.O. Emission of Trace Gases and Aerosols from Biomass Burning-an Updated Assessment. Atmos. Chem. Phys. 2019, 19, 8523-8546. [CrossRef] 